\title{
Large quantitative effect of melanocortin-4 receptor gene mutations on body mass index
}

\author{
A Dempfle, A Hinney, M Heinzel-Gutenbrunner, M Raab, F Geller, T Gudermann, H Schäfer, \\ $J$ Hebebrand
}

$\mathrm{T}$ he melanocortin-4 receptor gene $(M C 4 R)$ is involved in central energy homeostasis and body weight regulation. Both endogenous anorexigenic and orexigenic ligands bind to the receptor. ${ }^{1}$ Under normal conditions, the anorexigenic tone prevails as revealed by the fact that Mc4r knockout mice ${ }^{2}$ develop elevated body weight. $M c 4 r^{-1-}$ mice show higher food intake but a similar metabolic rate and similar decreased physical activity compared to wild type (WT) mice of the same strain..$^{2-4}$ In comparison to a standard low fat diet, this deviant regulation of energy homeostasis is even more pronounced upon intake of a moderately fat diet, ${ }^{5}$ which leads to an even higher body mass.

In all studies, the effect on body weight is smaller in heterozygous than in homozygous knockout mice, but the exact degree of dominance is not clear. In heterozygous

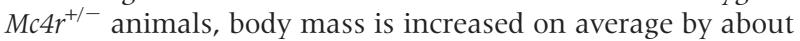
$7-45 \%$ and in homozygous $\mathrm{Mc}^{-1-} \mathrm{r}^{--}$by $50-100 \%$ compared to $\mathrm{WT}^{2-5}$ with substantial overlap between groups. The mutations might have a sex dependent effect, but the results are contradictory. In one study, the effect in males was only about half of that in females. ${ }^{2}$ However, two studies did not detect a sex by genotype interaction in this $M c 4 r^{-1-}$ strain. ${ }^{45}$ One study in a different knockout line of the same inbred strain found a sex by genotype interaction in the opposite direction, with only a marginal effect in heterozygous females whereas heterozygous males had a body weight intermediate between WT and homozygous knockouts. ${ }^{3}$

The first mutations in the human $M C 4 R$ gene were reported in extremely obese probands. ${ }^{6-8}$ Since then, several other studies investigated the association of different MC4R mutations with obesity. According to a recent overview, ${ }^{9}$ at least 34 putatively functionally relevant variants have been detected in several mutation screens. The variants encompass frameshift, nonsense, and missense mutations, most of which have been shown to lead to total or partial loss of function in appropriate in vitro assays. All mutations are rare, with reported combined frequencies for all functionally relevant mutations typically in the range of $2-3 \%$ in extremely obese individuals. ${ }^{9}$ In contrast, none of the putatively functionally relevant mutations have been found in controls. ${ }^{9}$ The two missense variants V103I and I25 IL have each been detected with similar frequencies in both cases and controls; I251L is presumed to be a non-functional polymorphism, ${ }^{10}$ while V103I shows a negative association with obesity as has recently been shown in a meta-analysis encompassing more than 7500 individuals. ${ }^{1}$

The quantitative effect of human MC4R mutations on body weight is currently unknown. Often the study design of screening phenotypically selected probands, for example extremely obese cases and normal weight controls, precludes such an analysis. It is assumed that these mutations more or less completely underlie the obesity of the respective carrier and this therefore is often referred to as a monogenic form of obesity. ${ }^{12-16}$ However, in family studies based on obese index

\section{Key points}

- Melanocortin-4 receptor gene (MC4R) mutations are known to cause obesity. The usual practice of ascertaining extremely obese probands to enhance the probability of detecting mutation carriers potentially leads to an overestimation of the phenotypic effects of these mutations.

- Our aim is to provide a more valid estimate of the effect of MC4R mutations by comparing the body weights of relatives of $M C 4 R$ mutation carriers, comprising 181 phenotypically unselected relatives of extremely obese index patients from 25 pedigrees.

- Carriers of functionally relevant mutations had a significantly higher current body mass index (BMI) than their wild type relatives. The observed effect was about twice as strong in females than in males, with BMI differences between mutation carriers and wild type relatives of approximately 2.5 and $1.3 \mathrm{SD}$, amounting to 9.5 and $4 \mathrm{~kg} / \mathrm{m}^{2}$ in middle aged women and men, respectively.

- Our findings clearly substantiate that MC4R mutations entail a strong predisposition to obesity. Both the high rate and the degree of adiposity among wild type relatives nevertheless suggest that other genetic and/or environmental effects contribute to the obesity seen in mutation carriers.

carriers, single relatives harbouring the same mutation have been identified who were only moderately overweight or even lean. ${ }^{10}{ }^{17}$ Whereas this can be explained by an underlying medical condition in single cases, ${ }^{17}$ the lean carriers identified by Vaisse et $a l^{10}$ were healthy. Recently, three missense mutations (which have not yet been functionally characterised) have also been found in a group of 48 controls with a body mass index (BMI) below $30 \mathrm{~kg} / \mathrm{m}^{2}{ }^{2}{ }^{18}$ Assessment of the effect size of MC4R mutations is further complicated by the fact that WT relatives of extremely obese mutation carriers are often also obese, ${ }^{15} 171920$ indicating that other genetic and/ or environmental factors are operative in these families, which accordingly could also contribute to the obesity of the index cases. It is well known that body weight is influenced by many genetic and environmental factors. Heritability estimates for BMI derived from family and twin studies range

Abbreviations: $\alpha-M S H, \alpha$-melanocyte stimulation hormone; BMI, body mass index; LOF, loss of function; MC4R, melanocortin-4 receptor gene; QTDT, Quantitative Transmission Disequilibrium Test; RF, reduced function; SDS, standard deviation score; SSCP, single strand conformation polymorphism; WT, wild type 
from $0.3-0.7$ to $0.6-0.8$, respectively. ${ }^{21}$ Evaluation of the phenotypic effects of $M C 4 R$ mutations has to take this polygenic, multifactorial context into account and cannot simply assume that mutation carriers identified in samples of extremely obese probands are obese only because of their mutations.

In this study, we estimate the quantitative effect of MC4R mutations on BMI in a sample of 25 pedigrees (three of which have been reported previously ${ }^{17}$ ) with segregating mutations using only relatives of extremely obese index patients. These relatives have the advantage of being enriched for mutations without being ascertained for severe obesity.

\section{METHODS}

\section{Study sample}

The sample is based on an MC4R mutation screen in 887 extremely obese children (BMI $\geqslant 90$ th age and sex specific percentile ${ }^{22}$ ) and both parents of 520 of these (slightly extended sample of Hinney et $a^{23}$ ). In 24 of the young index patients and in three parents of WT index patients, 17 different nonsense, missense, and frameshift mutations with potential functional relevance were detected (table 1). The two previously reported polymorphisms (V103I and I251L ${ }^{8}{ }^{10}$ ) are not considered further here.

Written informed consent was given by participants, or in case of minors by their parents; the study was approved by the Ethics Committee of the University of Marburg. Because all 27 mutation carriers (24 index patients, three parents) had indicated that they wanted to be recontacted in case of a positive molecular finding upon the initial assessment, we were able to get in touch with all of them and obtained permission to also contact additional family members. Two families declined to participate in an extended family study. One of these families was included as the originally ascertained trio only; the other had to be excluded as we had no phenotypical information pertaining to mutation carriers other than the index patient. A total of 24 extended pedigrees were recruited through the mutation carriers (one family was recruited independently via two index cases who are second cousins and carriers of the same mutation; see Sina $e t a l^{17}$ ) and all participating relatives were also screened by single strand conformation polymorphism (SSCP) analysis and independent confirmatory mutation analyses (PCR-RFLP and allele-specific PCR; see Hinney et $a^{23}$ ). SSCP is known to have a sensitivity of approximately $85 \%{ }^{24}$; PCR-RFLP and allele-specific PCR are very sensitive mutation-detection tools. ${ }^{25}$ We have performed both the SSCP and the independent mutation-specific analyses (PCR-RFLP or PCR with allele-specific primers) in duplicate, thus virtually eliminating the risk of undetected or wrongly classified mutations.

The final sample consisted of 284 subjects in 25 families comprising 3-30 individuals. A total of 207 subjects were both phenotyped and genotyped ( 98 males), the others define relationships between genotyped individuals. The 207 genotyped subjects included the 26 ( 23 with mutations) extremely obese index patients, 43 parents, 22 siblings, and 116 second or higher degree relatives. The mean (SD) age of the 207 genotyped individuals was 37.8 (19.4) years, ranging from 6 to 81 years.

The phenotype we considered was the standard deviation score (SDS) of both the current BMI and the recalled maximum lifetime BMI (using recalled maximum weight and currently measured height for adults; for children and adolescents the current weight was designated the maximum weight). SDS were derived from a large German population sample (German National Nutrition Survey ${ }^{22}{ }^{27}$ ) and have the advantage that they are independent of sex and age (in contrast to BMI itself), thus enabling comparisons across this sample of relatives in different generations. As in our previous family study, ${ }^{17}$ obesity was defined as a $\mathrm{BMI} \geqslant 85$ th age and sex specific percentile. ${ }^{28}$

\section{Classification of MC4R mutations}

In order to decide whether or not to consider different groups of mutations separately in the analysis, we evaluated all published information on putative functional relevance based on in vitro assays of the 17 mutations. ${ }^{1023} 29-34$ Assays that measured different properties of the receptor, and in some cases even the same assay performed by different groups, led to different conclusions about the functional relevance of mutations (table 1). Of the 17 mutations 16 have been shown to lead to a significant reduction of the receptor function as

Table 1 Putative function of the different mutations in the coding region of the MC4R gene segregating in the 26 families according to different assays

\begin{tabular}{|c|c|c|c|c|}
\hline \multirow[b]{2}{*}{$\begin{array}{l}\text { Amino acid } \\
\text { position and change }\end{array}$} & \multirow[b]{2}{*}{$\begin{array}{l}\text { Cell surface } \\
\text { expression }\end{array}$} & \multicolumn{2}{|l|}{ Ligand binding } & \multirow{2}{*}{$\begin{array}{l}\text { Signalling properties as } \\
\text { measured by cAMP } \\
\text { ( } \alpha-M S H) \text { assay }\end{array}$} \\
\hline & & $\mathrm{IC}_{50}$ & $\begin{array}{l}\text { Specific binding } \\
\text { (relative to WT) }\end{array}$ & \\
\hline $\begin{array}{ll}\text { S30F } & \\
{[Y 35 X} & D 37 Y]^{*}\end{array}$ & About $120 \%{ }^{31}$ & & & Like $\mathrm{WT}_{1}{ }^{23} \mathrm{RF}^{31}$ \\
\hline $\begin{array}{l}{[Y 35 X, D 37 V]^{*}} \\
\text { P78L } \\
\text { S94R }\end{array}$ & $31 \%,{ }^{31} 1 \%,{ }^{32} 0 \%^{34}$ & & About $10 \%^{32}$ & $\begin{array}{l}\mathrm{RF}^{23} \mathrm{LOF}^{, 31} \mathrm{LOF}^{34} \\
\mathrm{OF}^{23}\end{array}$ \\
\hline V95I & & & & $\operatorname{LOF}^{23}$ \\
\hline $\begin{array}{l}\text { T112M } \\
1121 T\end{array}$ & $41 \%^{32}$ like $W^{35}$ & Sign. reduced ${ }^{32}$ & & $\begin{array}{l}\text { Like WT, }{ }^{29} \text { like } \mathrm{WT}^{35} \\
\mathrm{RF}^{23}\end{array}$ \\
\hline S127L & $101 \%{ }^{31}$ like $W^{35}$ & & & Const. active, ${ }^{23} \mathrm{RF}_{1}{ }^{31} \mathrm{RF}^{35}$ \\
\hline R165W & $26 \%{ }^{31} 9 \%^{32}$ & & About $0 \%{ }^{10}$ & $\mathrm{RF}^{10}$ \\
\hline $\begin{array}{l}\text { G181D } \dagger \\
\end{array}$ & & & & $\operatorname{LOF}^{23}$ \\
\hline $\begin{array}{l}\text { L21 1fsX216 } \\
\text { P230L }\end{array}$ & $0 \%^{30}$ & & $0 \%{ }^{30}$ & $\begin{array}{l}\text { LOF, }^{23} \text { LOF, }^{31} \text { LOF }^{30} \\
\text { Const active }\end{array}$ \\
\hline $\begin{array}{l}\text { P230L } \\
\text { A244E } \\
\text { L250fsX284 }\end{array}$ & $90 \%{ }^{31}$ & & & $\begin{array}{l}\text { Const. active }{ }^{23} \\
\mathrm{RF}^{23} \mathrm{RF}^{31} \\
\mathrm{LOF}^{23}\end{array}$ \\
\hline G252S & About $100 \%{ }^{31}$ & & & Like $\mathrm{WT}_{1}^{23} \mathrm{RF}^{31}$ \\
\hline $1317 T$ & $\begin{array}{l}66 \%{ }^{31} 42 \%{ }^{32} \\
\text { reduced }^{33}\end{array}$ & & About $42 \%^{32}$ & Like WT, ${ }^{23} \mathrm{RF}^{31} \mathrm{RF}^{33}$ \\
\hline Y320fsX354 & & & & $\mathrm{RF}^{23}$ \\
\hline
\end{tabular}

*The Y35X and D37V mutations only occur together on a haplotype and thus are not analysed separately; tThe G181D mutation only occurred in an extremely obese index patient but not in his two available relatives and could therefore not be included in the statistical analysis.

LOF, loss of function; RF, reduced function. 
measured by cell surface expression, ligand binding ( $\mathrm{IC}_{50}$ values and specific binding relative to WT), and/or signal transduction ( $\alpha$-melanocyte stimulation hormone $(\alpha-\mathrm{MSH})$ stimulated cAMP signalling). One mutation (P230L) has been shown to be constitutively active in the cAMP assay, ${ }^{23}$ as characterised by increased basal cAMP levels, but also showed a clear impairment in $\mathrm{EC}_{50}$ values. Additionally, such mutations often have decreased cell surface expression, ${ }^{32}$ and therefore we classified this mutation as also resulting in functional impairment. Results and interpretation of the published functional assays are not consistent enough to group mutations by different levels of functional impairment such as total loss of function and merely reduced function. In conclusion, all 17 identified mutations were classified as leading to an impaired receptor function. Accordingly, for the main statistical analyses we regarded them as equivalent and included a descriptive analysis of all mutations separately.

The two polymorphisms (V103I and I25IL) were coded as WT and therefore not included in the effect estimation: V103I has been shown to be negatively associated with obesity ${ }^{11}$; I25 IL occurs with a similar frequency of $0.5-2 \%$ in obese and normal subjects in different populations ${ }^{8} 15182335$ and behaves like WT in the cAMP assay. ${ }^{10}$

The distribution of genotypes in index patients and relatives in the study sample is shown in table 2 . Two of the index patients (one male, one female) were compound heterozygous mutation carriers, whereas none of the relatives carried two mutations. The female compound heterozygous mutation carrier (with mutations S30F and S127L) was the most obese in our study group with a current BMI of $65.6 \mathrm{~kg} /$ $\mathrm{m}^{2}$ (BMI SDS of 15.9), while the male compound heterozygous mutation carrier (mutations R165W and G252S) had a current BMI of $41.6 \mathrm{~kg} / \mathrm{m}^{2}$ (BMI SDS of 7.07).

\section{Statistical analyses}

All statistical analyses were done without the index patients, because their inclusion would have led to biased estimates due to their ascertainment on the basis of their extreme obesity.

We tested for differences in current and maximum BMI SDS with the Quantitative Transmission Disequilibrium Test (QTDT), ${ }^{36}$ a generalisation of the transmission/disequilibrium test $^{37}$ for quantitative phenotypes in general pedigrees which gives a valid test for association while accounting for correlations between relatives. Here, major gene effects through linkage and association are modelled separately in a variance components framework. The model takes into account the specific family structure of each pedigree and resulting correlations caused by polygenic and/or common environmental factors. Because the phenotypes are not normally distributed in this selected sample, significance was tested by a randomisation test (with 50000 permutations), where transmitted and non-transmitted alleles in each meiosis are permutated. Finally, the expected mean BMI

\begin{tabular}{|c|c|c|c|}
\hline & $\begin{array}{l}\text { Homozygous } \\
\text { WT }\end{array}$ & $\begin{array}{l}\text { Heterozygous } \\
\text { mutation } \\
\text { carriers }\end{array}$ & $\begin{array}{l}\text { Compound } \\
\text { heterozygous } \\
\text { mutation carriers }\end{array}$ \\
\hline $\begin{array}{l}\text { Index patients, } \\
\text { First degree } \\
\text { relatives, }\end{array}$ & $\begin{array}{r}3 \\
29\end{array}$ & $\begin{array}{l}21 \\
36\end{array}$ & $\begin{array}{l}2 \\
-\end{array}$ \\
\hline $\begin{array}{l}\text { Second and } \\
\text { higher degree } \\
\text { relatives, }\end{array}$ & 86 & 30 & - \\
\hline
\end{tabular}

SDS was estimated for WT and mutation carriers by inserting the obtained regression parameters into the respective equations. The difference between these means is the quantitative displacement attributable to the mutation. A one-sided 95\% confidence interval (CI) for this displacement estimate was calculated as the difference which results in a $\mathrm{p}$ value of 0.05 in the randomisation test. ${ }^{38}$ To investigate a possible sex by genotype interaction, we tested separately for differences between female mutation carriers and females with the WT genotype (by setting the phenotypes of all males to missing, while retaining their genotypes) and analogously between male mutation carriers and males with the WT genotype.

QTDT effectively compares the BMI SDS of individuals with a heterozygous parent from whom the mutation was transmitted with those who did not inherit the mutation. The family structure is also included in the QTDT model so that basically a comparison within sibships is performed to separate effects of the gene of interest from other polygenic and/or environmental effects.

On a descriptive basis, we also considered all mutations separately and calculated the mean per-family difference in BMI SDS between all WT and mutation carriers (again excluding index patients). For mutations which occurred in more than one family, relatives were weighted so each family contributed equally to the respective estimate.

\section{RESULTS}

The permutation QTDT revealed a significant difference in current BMI SDS between WT individuals and mutation carriers within a family of approximately 1.8 (with a lower bound of a one-sided confidence interval of 0.6; table 3). For maximum lifetime BMI, the difference between carriers and non-carriers is even slightly larger than the difference in current BMI SDS. This effect of MC4R mutations is stronger in females than in males (no p value for the interaction can be given by QTDT). The average current SDS of male and female mutation carriers correspond to BMIs of 31.9 and $36.2 \mathrm{~kg} / \mathrm{m}^{2}$, respectively, for subjects in the age range 3040 years, whereas the average male and female WT carriers in our sample have corresponding BMIs of 27.9 and $26.7 \mathrm{~kg} / \mathrm{m}^{2}$. Therefore the mutations account for respective BMI elevations of $14 \%$ and $36 \%$ above the average WT BMI in these families. In contrast to the apparent difference among mutation carriers, WT males and females have very similar BMI SDS. The estimated mean current and maximum lifetime BMI SDS for both WT and mutation carriers are clearly higher than the population means of 0 (table 3 ).

A descriptive analysis of the effects of each single mutation is shown in table 4 , giving the mean per-family difference in current BMI SDS between mutation carriers and WT carriers. The effects range from -2.02 to 2.70 SDS.

On a descriptive basis, the rates for current and lifetime obesity decrease more strongly among WT than mutation carriers with respect to degree of relationship to the proband (table 5). Because of the mentioned ascertainment effect, these rates are much higher than in a population sample and only comparisons between mutation carriers and WT carriers within families are valid.

\section{DISCUSSION}

We have, for the first time, systematically estimated the quantitative effect of $M C 4 R$ mutations on BMI. Morton ${ }^{39}$ used the expression "major gene" for a quantitative phenotype with a displacement greater than 1 SD. Thus, the observed difference of almost $2 \mathrm{SD}$ for current BMI suggests that relevant mutations in the $M C 4 R$ gene indicate it is a major gene for the development of obesity. The observed effect was about twice as strong in females than in males and 
Table 3 Mean current and maximum lifetime BMI SDS by genotype for informative families as revealed by QTDT analysis

\begin{tabular}{|c|c|c|c|c|c|c|c|c|c|}
\hline \multirow[b]{2}{*}{ Sample } & \multirow[b]{2}{*}{$\begin{array}{l}\text { Number of } \\
\text { informative } \\
\text { individuals }\end{array}$} & \multicolumn{4}{|c|}{ Mean current BMI SDS } & \multicolumn{4}{|c|}{ Mean maximum lifetime BMI SDS } \\
\hline & & $\begin{array}{l}\text { WT } \\
\text { carriers }\end{array}$ & $\begin{array}{l}\text { Mutation } \\
\text { carriers }\end{array}$ & $\begin{array}{l}\text { Lower bound of one-sided } \\
95 \% \mathrm{Cl} \text { of mean difference } \\
\text { between WT and mutation } \\
\text { carriers }\end{array}$ & p Value & $\begin{array}{l}\text { WT } \\
\text { carriers }\end{array}$ & $\begin{array}{l}\text { Mutation } \\
\text { carriers }\end{array}$ & $\begin{array}{l}\text { Lower bound of one-sided } \\
95 \% \mathrm{Cl} \text { of mean difference } \\
\text { between WT and mutation } \\
\text { carriers }\end{array}$ & p Value \\
\hline All relatives & 82 & $1.00^{*}$ & 2.82 & 0.57 & 0.0112 & 1.60 & 3.57 & 0.9 & 0.0024 \\
\hline Females only & 43 & 0.95 & 3.41 & 0.77 & 0.0094 & 1.58 & 4.14 & 0.98 & 0.0052 \\
\hline Males only & 39 & 0.99 & 2.27 & 0.14 & 0.0284 & 1.52 & 3.12 & 0.46 & 0.0015 \\
\hline
\end{tabular}

corresponds to a difference in current BMI of approximately $9.5 \mathrm{~kg} / \mathrm{m}^{2}$ for females and $4.0 \mathrm{~kg} / \mathrm{m}^{2}$ for males in the age range $30-40$ years. This represents BMI elevations of $14 \%$ and $36 \%$ above the average WT BMI in these families. These results are consistent with animal studies, in which heterozygous $\mathrm{Mc} 4 \mathrm{r}^{+/-}$mice also showed an average increase in body weight of $7-45 \%$ compared to WT littermates. Our observed sex effect is also similar to the results of the original ${\mathrm{Mc} 4 \mathrm{r}^{-1-}}^{-1}$ model. ${ }^{2}$

The obesity of MC4R mutation carriers has previously been termed monogenic. ${ }^{12-16}$ Although our results indeed point to a strong quantitative effect, it should be noted that the differences in current BMI between WT and mutation carriers of 4 and $9.5 \mathrm{~kg} / \mathrm{m}^{2}$ for males and females, respectively, do not necessarily imply the development of obesity. Indeed, lean mutation carriers have been observed ${ }^{10}$ who may not have crossed the threshold to severe obesity due to other, as yet unidentified, modifier genes and/or environmental factors. The rates of obesity in our WT carriers (table 5) illustrate that in these families, including the mutation carriers, other influences predisposing to an elevated body weight are operative. As expected for a multifactorial disorder, rates of obesity drop substantially between the first and second degree WT relatives of the index patients. In contrast, this decline is considerably less pronounced among the mutation carrying relatives, again underscoring the major effect of MC4R mutations (table 5). In the light of these considerations we prefer the term major gene effect instead of monogenic for MC4R mutations. Like Morton, ${ }^{39}$ we use this expression in the sense of a high individual risk for

Table 4 Mean current BMI SDS difference between WT and mutation carrying relatives within families for single mutations

\begin{tabular}{lllll}
\hline $\begin{array}{l}\text { Amino acid } \\
\text { position and } \\
\text { change }\end{array}$ & $\begin{array}{l}\text { Number of } \\
\text { families } \\
\text { segregating } \\
\text { this mutation }\end{array}$ & $\begin{array}{l}\text { Number of } \\
\text { WT } \\
\text { individuals }\end{array}$ & $\begin{array}{l}\text { Number of } \\
\text { mutation } \\
\text { carriers }\end{array}$ & $\begin{array}{l}\text { Mean BMI } \\
\text { SDS } \\
\text { difference }\end{array}$ \\
\hline S30F & 2 & 18 & 4 & 1.2 \\
[Y35X, & 8 & 23 & 22 & 1.05 \\
D37V] & & & & \\
P78L & 1 & 10 & 2 & 0.43 \\
S94R & 1 & 1 & 2 & 1.04 \\
V95I & 1 & 3 & 2 & -1.5 \\
T112M & 1 & 2 & 2 & 0.56 \\
I121T & 1 & 3 & 2 & -0.57 \\
S127L & 3 & 12 & 6 & 2.18 \\
R165W & 1 & 7 & 4 & 2.08 \\
L211fsX216 & 2 & 19 & 10 & 2.70 \\
P230L & 1 & 10 & 2 & 1.84 \\
A244E & 1 & 5 & 4 & 0.50 \\
L250fsX284 & 1 & 1 & 1 & -0.21 \\
G252S & 1 & 2 & 16 & 2.13 \\
I317T & 1 & 2 & 1 & -2.02 \\
Y320fsX354 & 1 & 5 & 2 & 0.14 \\
\hline
\end{tabular}

a complex, quantitative trait without implying a high population attributable risk (due to the rareness of these mutations).

Because of our sampling scheme we are unable to draw definite conclusions for mutation carriers with a genetic and/ or environmental predisposition to leanness; in principle our results are only generalisable to relatives of obese probands living in our current (German) obesigenic environment. If $M C 4 R$ mutations have an additive effect independent of other genetic and/or environmental factors, the observed difference in BMI should be approximately constant over the whole BMI range. The effect of ascertainment on parameter estimates was previously shown in the penetrance estimation of the breast cancer 1 gene $(B R C A 1)$ on breast cancer $^{40}$ : the highest penetrance estimates were obtained in studies of "high-risk" families with at least four affecteds. ${ }^{41}$ Lower estimates were derived from studies based on cases ascertained independently of family history. ${ }^{42}$ Even lower estimates were obtained in a population based study. ${ }^{43}$ The explanation for this systematic trend results from the overrepresentation of all risk factors in cases and even more so in "high-risk" families. Our displacement estimate would be similarly inflated if we had compared the BMI of the mutation carrying relatives of our extremely obese index patients with those of the general population (for example, by testing whether the BMI SDS of these relatives have a mean of 0 ). The effect of ascertainment can also be seen in the high rate of obesity among these relatives (table 5) and has to be taken into account properly in the analysis. However, we evaluated the difference between mutation carriers and WT carriers within families upon exclusion of index patients, which reduces the ascertainment bias substantially. Exclusion of index patients is important because they were recruited based on their extreme phenotypes and are almost all mutation carriers (23 out of 26 ). A completely unbiased estimation of phenotypic effects of MC4R mutations is only possible with a population based sample, which would have to be prohibitively large due to the very low frequency of these mutations in the general population.

In six other human studies, ${ }^{70} 19203144$ the body weight in SDS of genotyped family members of index patients has

Table 5 Rates of obesity among WT and mutation carriers, percentage currently and ever above 85th sex and age specific BMI percentile

\begin{tabular}{lcclll}
\hline & \multicolumn{2}{l}{ Currently obese } & & \multicolumn{2}{l}{ Ever obese } \\
\cline { 2 - 3 } \cline { 5 - 6 } \cline { 5 - 5 } & WT & $\begin{array}{l}\text { Mutation } \\
\text { carriers }\end{array}$ & & WT & $\begin{array}{l}\text { Mutation } \\
\text { carriers }\end{array}$ \\
\hline Index patients & $100 \%$ & $100 \%$ & & $100 \%$ & $100 \%$ \\
First degree relatives & $68 \%$ & $92 \%$ & & $81 \%$ & $97 \%$ \\
Second and higher & $50 \%$ & $80 \%$ & & $58 \%$ & $97 \%$ \\
degree relatives & & & & \\
\hline
\end{tabular}


previously been presented. In 14 families, data on 46 first degree relatives with different genotypes were reported, and data on 17 second and higher degree relatives for six of these families. Based on these data, we calculated that the mean difference between mutation carriers and WT with the same degree of relationship to the proband within a family is 2.1 SDS and thus similar to the results obtained in our systematic analysis.

For our statistical analyses, mutations had to be grouped since most are individually too rare to draw meaningful conclusions. ${ }^{9}$ After careful consideration of all available functional data, we decided to consider only one group despite the fact that the different mutations might exert different quantitative effects in vivo; all those mutations were included for which in vitro characterisations have indicated or suggested an impaired function. ${ }^{10}{ }^{23}{ }^{29-34}$ Our decision to form only one group was based on the limited number of available families and the fact that different functional assays have rendered divergent and sometimes inconsistent results as to the degree of functional impairment of specific mutations. Furthermore, most mutations have not yet been fully tested for all experimentally accessible functions (for example, signalling properties, binding of endogenous ligands, cell surface expression; see table 1), so that a final classification based on such detailed in vitro results is not yet possible. Ultimately, a classification of MC4R mutations should be based on both functional and quantitative phenotypic data.

As expected, a separate consideration of single mutations showed large variation in effect estimates (table 4). In some families, mutation carriers had even smaller BMI SDS than WT carriers, again underlining that among individual members of a particular family other factors, such as polygenic background, other major genes, and environmental factors also play an important role in body weight regulation. Clearly, random variation in other factors adds to the quantitative differences in BMI SDS of carriers of the same mutation. The mean effect of each single mutation on the phenotype can only be estimated reliably from a large enough population or family based sample. Because most of our detected mutations segregated in only one single family with a limited number of mutation carriers and WT individuals, respectively, this expected random variation also contributes to the interfamilial differences in observed effects of different mutations.

However, the observed interfamilial differences in effect sizes are also due to the fact that different mutations likely imply a quantitative range of functional impairment theoretically ranging from enhanced function (as suggested for V103I or an associated variant ${ }^{11}$ ), no functional effect-even if in vitro results indicate a reduced function, this does not necessarily apply in vivo-to a more or less complete loss of MC4R function due to a dominant negative effect. In this context, it is of interest that the most commonly detected MC4R mutation (Y35X), which was detected in eight families with a total of 44 relatives plus eight index patients, resulted in a difference of only 1.05 SD between mutation and WT carriers. The respective mutation most likely leads to haploinsufficiency for $M C 4 R^{45}$ because the short $\mathrm{N}$-terminal sequence is presumably rapidly degraded upon translation. In contrast, other mutations could entail a dominant negative effect, ${ }^{45}$ thus rendering the quantitative effect of such mutations even stronger than haplo-insufficiency. This could be the case for the mutation with the highest observed BMI increase (2.70 SDS; L211fsX216). To what extent dominant negativity plays a role in $M C 4 R$ signalling is not yet fully elucidated. ${ }^{3045}$ It seems that the mutation for which the least functional evidence of an impaired receptor function is available (the constitutively active mutation P230L) shows a similar effect on BMI as the combined sample of all mutations. Additional family studies offer a powerful approach to indeed clarify if such constitutively active mutations entail a strong quantitative effect on BMI in vivo.

In conclusion, our approach of recruiting relatives of known mutation carriers is a solid strategy to estimate the quantitative effect of genetic variants in a sample enriched for mutation carriers. Such family studies should complement functional in vitro studies as these cannot readily be related to the in vivo effect of a particular mutation, and pedigree analyses represent the only way to estimate the quantitative effect on BMI in humans for such rare mutations. Our results indicate that adult male and female $M C 4 R$ mutation carriers have an increased risk of obesity, which amounts to a BMI elevated by approximately 4 and $9.5 \mathrm{~kg} / \mathrm{m}^{2}$, respectively, in comparison to their WT relatives in families of obese index patients.

\section{ACKNOWLEDGEMENTS}

We thank Dr Heike Biebermann for her very helpful comments.

\section{Authors' affiliations}

A Dempfle, M Heinzel-Gutenbrunner, F Geller, H Schäfer, Institute of Medical Biometry and Epidemiology, Philipps-University Marburg, Marburg, Germany

A Hinney, M Raab, J Hebebrand, Clinical Research Group, Department of Child and Adolescent Psychiatry, Philipps-University Marburg, Marburg, Germany

T Gudermann, Institute of Pharmacology and Toxicology, PhilippsUniversity Marburg, Marburg, Germany

This research was supported by grants 01 GS0203 and 01GS01 18 from the German Bundesministerium für Bildung und Forschung (National Genome Net).

Conflict of interest: none declared.

Correspondence to: Dr J Hebebrand, Clinical Research Group, Department of Child and Adolescent Psychiatry, Philipps-University Marburg, Schützenstraße 49, 35033 Marburg, Germany; Johannes. Hebebrand@med.uni-marburg.de

Revised version received 25 March 2004

Accepted for publication 18 April 2004

\section{REFERENCES}

1 Marks DL, Butler AA, Cone RD. Melanocortin pathway: animal models of obesity and disease. Ann Endocrinol 2002;63:121-4.

2 Huszar D, Lynch CA, Fairchild-Huntress V, Dunmore JH, Fang Q, Berkemeier LR, Gu W, Kesterson RA, Boston BA, Cone RD, Smith FJ, Campfield LA, Burn P, Lee F. Targeted disruption of the melanocortin-4 receptor results in obesity in mice. Cell 1997;88:131-41.

3 Chen AS, Metzger JM, Trumbauer ME, Guan XM, Yu H, Frazier EG, Marsh DJ, Forrest MJ, Gopal-Truter S, Fisher J, Camacho RE, Strack AM, Mellin TN, Maclntyre DE, Chen HY, Van der Ploeg LH. Role of the melanocortin-4 receptor in metabolic rate and food intake in mice. Transgenic Res 2000;9: 145-54.

4 Weide K, Christ N, Moar KM, Arens J, Hinney A, Mercer JG, Eiden S Schmidt I. Hyperphagia, not hypometabolism, causes early onset obesity in melanocortin-4 receptor knockout mice. Physiol Genomics 2003;13:47-56.

5 Butler AA, Marks DL, Fan W, Kuhn CM, Bartolome M, Cone RD. Melanocortin-4 receptor is required for acute homeostatic responses to increased dietary fat. Nat Neurosci 2001;4:605-11.

6 Yeo GS, Farooqi IS, Aminian S, Halsall DJ, Stanhope RG, O'Rahilly S. A frameshift mutation in MC4R associated with dominantly inherited human obesity. Nat Genet 1998;20:111-2.

7 Vaisse C, Clement K, Guy-Grand B, Froguel P. A frameshift mutation in human MC4R is associated with a dominant form of obesity. Nat Genet 1998;20:113-4.

8 Hinney A, Schmidt A, Nottebom K, Heibult O, Becker I, Ziegler A, Gerber G, Sina M, Gorg T, Mayer H, Siegfried W, Fichter M, Remschmidt H, Hebebrand J. Several mutations in the melanocortin-4 receptor gene including a nonsense and a frameshift mutation associated with dominantly inherited obesity in humans. J Clin Endocrinol Metab 1999;84:1483-6.

9 Hirschhorn JN, Altshuler D. Once and again-issues surrounding replication in genetic association studies. J Clin Endocrinol Metab 2002;87:4438-41.

10 Vaisse C, Clement K, Durand E, Hercberg S, Guy-Grand B, Froguel P. Melanocortin-4 receptor mutations are a frequent and heterogeneous cause of morbid obesity. J Clin Invest 2000; 106:253-62. 
11 Geller F, Reichwald K, Dempfle A, Illig T, Vollmert C, Herpertz S, Siffert W, Platzer M, Hess C, Gudermann T, Biebermann H, Wichmann HE, Schafer H, Hinney A, Hebebrand J. Melanocortin-4 receptor gene variant i103 is negatively associated with obesity. Am J Hum Genet 2004;74:572-81

12 Mergen M, Mergen H, Ozata M, Oner R, Oner C. A novel melanocortin 4 receptor (MC4R) gene mutation associated with morbid obesity. J Clin Endocrinol Metab 2001;86:3448

13 Kobayashi H, Ogawa Y, Shintani M, Ebihara K, Shimodahira M, Iwakura T, Hino M, Ishihara T, Ikekubo K, Kurahachi H, Nakao K. A novel homozygous missense mutation of melanocortin-4 receptor (MC4R) in a Japanese woman with severe obesity. Diabetes 2002;51:243-6.

14 Tsigos C, Kyrou I, Raptis SA. Monogenic forms of obesity and diabetes mellitus. J Pediatr Endocrinol Metab 2002;15:241-53.

15 Marti A, Corbalan MS, Forga L, Martinez JA, Hinney A, Hebebrand J. A novel nonsense mutation in the melanocortin- 4 receptor associated with obesity in a Spanish population. Int J Obes Relat Metab Disord 2003;27:385-8.

16 Farooqi IS, Keogh JM, Yeo GS, Lank EJ, Cheetham T, O'Rahilly S. Clinical spectrum of obesity and mutations in the melanocortin 4 receptor gene. N Engl J Med 2003;348:1085-95.

17 Sina M, Hinney A, Ziegler A, Neupert T, Mayer H, Siegfried W, Blum WF, Remschmidt $\mathrm{H}$, Hebebrand J. Phenotypes in three pedigrees with autosoma dominant obesity caused by haploinsufficiency mutations in the melanocortin 4 receptor gene. Am J Hum Genet 1999:65:1501-7.

18 Jacobson P, Ukkola O, Rankinen T, Snyder EE, Leon AS, Rao DC, Skinner JS Wilmore JH, Lonn L, Cowan GS Jr, Sjostrom L, Bouchard C. Melanocortin 4 receptor sequence variations are seldom a cause of human obesity: the Swedish Obese Subjects, the HERITAGE Family Study, and a Memphis cohort. J Clin Endocrinol Metab 2002;87:4442-6.

19 Dubern B, Clement K, Pelloux V, Froguel P, Girardet JP, Guy-Grand B, Tounian P. Mutational analysis of melanocortin-4 receptor, agouti-related protein, and alpha-melanocyte-stimulating hormone genes in severely obese children. J Pediatr 2001;139:204-9.

20 Miraglia DG, Cirillo G, Nigro V, Santoro N, D'Urso L, Raimondo P, Cozzolino D, Scafato D, Perrone L. Low frequency of melanocortin-4 receptor (MC4R) mutations in a Mediterranean population with early-onset obesity. Int J Obes Relat Metab Disord 2002;26:647-51.

21 Hebebrand J, Friedel S, Schauble N, Geller F, Hinney A. Perspectives: molecular genetic research in human obesity. Obes Rev 2003;4:139-46.

22 Hebebrand J, Himmelmann GW, Heseker H, Schäfer H, Remschmidt H. Use of percentiles for the body mass index in anorexia nervosa: diagnostic, epidemiological and therapeutic considerations. Int J Eat Disord 1996; 19:359-69.

23 Hinney A, Hohmann S, Geller F, Vogel C, Hess C, Wermter AK, Brokamp B, Goldschmidt H, Siegfried W, Remschmidt H, Schafer H, Gudermann T, Hebebrand J. Melanocortin-4 receptor gene: case-control study and transmission disequilibrium test confirm that functionally relevant mutations are compatible with a major gene effect for extreme obesity. J Clin Endocrinol Metab 2003;88:4258-67

24 Jones AC, Austin J, Hansen N, Hoogendoorn B, Oefner PJ, Cheadle JP, O'Donovan MC. Optimal temperature selection for mutation detection by denaturing HPLC and comparison to single-stranded conformation polymorphism and heteroduplex analysis. Clin Chem 1999;45:1133-40.

25 Parsons BL, Heflich RH. Genotypic selection methods for the direct analysis of point mutations. Mutat Res 1997;387:97-121.

26 Krawczak M, Reiss J, Schmidtke J, Rosler U. Polymerase chain reaction: replication errors and reliability of gene diagnosis. Nucleic Acids Res 1989;17:2197-201.

27 Cole TJ. The LMS method for constructing normalized growth standards. Eur J Clin Nutr 1990;44:45-60

28 Cronk CE, Roche AF. Race- and sex-specific reference data for triceps and subscapular skinfolds and weight/stature. Am J Clin Nutr 1982:35:347-54

29 Gu W, Tu Z, Kleyn PW, Kissebah A, Duprat L, Lee J, Chin W, Maruti S, Deng N, Fisher SL, Franco LS, Burn P, Yagaloff KA, Nathan J, Heymsfield S
Albu J, Pi-Sunyer FX, Allison DB. Identification and functional analysis of novel human melanocortin-4 receptor variants. Diabetes 1999;48:635-9.

30 Ho G, MacKenzie RG. Functional characterization of mutations in melanocortin-4 receptor associated with human obesity. J Biol Chem 1999:274:35816-22

31 Lubrano-Berthelier C, Durand E, Dubern B, Shapiro A, Dazin P, Weill J, Ferron C, Froguel P, Vaisse C. Intracellular retention is a common characteristic of childhood obesity-associated MC4R mutations. Hum Mol Genet 2003;12:145-53.

32 Nijenhuis WA Garner KM, VanRozen RJ, Adan RA. Poor cell surface expression of human melanocortin- 4 receptor mutations associated with obesity. J Biol Chem 2003;278:22939-45.

33 VanLeeuwen D, Steffey ME, Donahue C, Ho G, MacKenzie RG. Cell surface expression of the melanocortin-4 receptor is dependent on a C-terminal diisoleucine sequence at codons 316/317. I Biol Chem 2003:278:15935-40.

34 Tao YX, Segaloff DL. Functional characterization of melanocortin-4 receptor mutations associated with childhood obesity. Endocrinology 2003; 144:4544-51.

35 Valli-Jaakola K, Lipsanen-Nyman M, Oksanen L, Hollenberg AN, Kontula K, Biorbaek C, Schalin-Jantti C. Identification and characterization of melanocortin-4 receptor gene mutations in morbidly obese Finnish children and adults. J Clin Endocrinol Metab 2004;89:940-5.

36 Abecasis GR, Cookson WO, Cardon LR. Pedigree tests of transmission disequilibrium. Eur J Hum Genet 2000;8:545-51.

37 Spielman RS, McGinnis RE, Ewens WJ. Transmission test for linkage disequilibrium: the insulin gene region and insulin-dependent diabetes mellitus (IDDM). Am J Hum Genet 1993;52:506-16.

38 Good P. Permutation tests, Springer Series in Statistics. New York: Springer, 1994.

39 Morton NE. Significance levels in complex inheritance. Am J Hum Genet 1998;62:690-7.

40 Begg CB. On the use of familial aggregation in population-based case probands for calculating penetrance. J Natl Cancer Inst 2002;94:1221-6.

41 Ford D, Easton DF, Stratton M, Narod S, Goldgar D, Devilee P, Bishop DT, Weber B, Lenoir G, Chang-Claude J, Sobol H, Teare MD, Struewing J, Arason A, Scherneck S, Peto J, Rebbeck TR, Tonin P, Neuhausen S, Barkardottir R, Eyfjord J, Lynch H, Ponder BA, Gayther SA, Birch JM, Lindblom A, Stoppa-Lyonnet D, Bignon Y, Borg A, Hamann U, Haites N, Scott RJ, Maugard CM, Vasen H, Seitz S, Cannon-Albright LA, Schofield A, Zelada-Hedman M, the Breast Cancer Linkage Consortium. Genetic heterogeneity and penetrance analysis of the BRCA1 and BRCA2 genes in breast cancer families. Am J Hum Genet 1998;62:676-89.

42 Warner E, Foulkes W, Goodwin P, Meschino W, Blondal J, Paterson C, Ozcelik H, Goss P, Allingham-Hawkins D, Hamel N, Di Prospero L, Contiga V, Serruya C, Klein M, Moslehi R, Honeyford J, Liede A, Glendon G, Brunet JS, Narod S. Prevalence and penetrance of BRCA1 and BRCA2 gene mutations in unselected Ashkenazi Jewish women with breast cancer. J Natl Cancer Inst 1999:91:1241-7.

43 Struewing JP, Hartge P, Wacholder S, Baker SM, Berlin M, McAdams M, Timmerman MM, Brody LC, Tucker MA. The risk of cancer associated with specific mutations of BRCA1 and BRCA2 among Ashkenazi Jews. NEngl J Med 1997:336:1401-8

44 Faroogi IS, Yeo GS, Keogh JM, Aminian S, Jebb SA, Butler G, Cheetham T, $\mathrm{O}$ 'Rahilly S. Dominant and recessive inheritance of morbid obesity associated with melanocortin 4 receptor deficiency. J Clin Invest 2000;106:271-9.

45 Biebermann H, Krude H, Elsner A, Chubanov V, Gudermann T, Gruters A Autosomal-dominant mode of inheritance of a melanocortin-4 receptor mutation in a patient with severe early-onset obesity is due to a dominant-negative effect caused by receptor dimerization. Diabetes 2003;52:2984-8

46 Yeo GS, Lank EJ, Faroogi IS, Keogh J, Challis BG, O'Rahilly S. Mutations in the human melanocortin-4 receptor gene associated with severe familial obesity disrupts receptor function through multiple molecular mechanisms. Hum Mol Genet 2003;12:561-74. 